\title{
The Development Concept of Mobile Augmented Reality (MAR) as an Innovation to Improve Tourism Experience (Study Case in Denpasar City, Bali).
}

\author{
Fannisa $^{1}$, Herry Irawan $^{2}$, Astri Ghina ${ }^{3}$ \\ fansafir@student.telkomuniversity.ac.id ${ }^{1}$, herryir@telkomuniversity.ac.id ${ }^{2}$, \\ aghina@telkomuniversity.ac.id ${ }^{3}$
}

School of Economic and Business Telkom University, Bandung, Indonesia

\begin{abstract}
The evolution of technology has impacted many fields, especially in the tourism sector which has a positive trend every year in Indonesia. Enhancement of internet and mobile phone users is also one of the reasons why the sectors are digitalized, it also certainly opens opportunities for mobile app developers especially for the games category as the top global mobile apps ranked to explore tourism. Tourism has taken steps to use AR to enhance the tourism experience. Some studies also state that AR is an effective way to promote and deliver information to a broad audience compared to other technologies. However, the existing features are considered less attractive to attracting tourists and have not provided value-added more than just providing information. It has become a problem yet an opportunity to develop the concept of Mobile Augmented Reality (MAR) in the tourism sector, especially in Denpasar's city case with low tourist visits. We propose a Design Thinking theory with a Text Mining approach to explore hidden information based on the user's perspective, and descriptive methods to find new design solutions based on their needs and desires. We find that lack of information is one that causes Denpasar's case. The majority $(91 \%)$ of respondents stated that they would be interested in using Tourism MAR to enhance their experience, which the features can fulfill three realms of experiences; entertainment, aesthetic, and escapism with visual information as an additional aspect.
\end{abstract}

Keywords: Experience, Design Thinking, Tourism.

\section{Introduction}

Tourism is one of the sectors in industries with positive trends every year. Indonesian tourist arrivals data showed an increasing trend every year, especially in 2018, Indonesia has reached 15.8 million visitors, an increase of 12.6 percent compared to 2017 of 14 million visits [1]. UNWTO also announced tourism as the leading sector and represented one of the most crucial sectors in the country's development [2]. Indonesia's president, Joko Widodo in "rapat terbatas", also stated that tourism is a sector that has unlimited resources, and it 
would be able to increase the needs of the largest foreign exchange earners above other sectors [3].

Indonesia has several entry points to choose from, by land, air, or sea, which are used as entrances by foreign tourists. Bali Ngurah Rai airport is the most traversed entrance by foreign tourists to enter Indonesian territory with as many as 6,025,760 million International tourist arrivals in 2018 [1]. It makes Bali become the province with the most tourist visits in Indonesia. However, the places visited by tourists when visiting Bali are not too diverse. It was proven by Bali foreign tourist statistics book in 2018, which shows there is a high gap in tourist visits between every regency in Bali. Bali has three of the most visited regencies: Tabanan Regency, Badung Regency, and Gianyar Regency. However, Denpasar as the capital and the center of government of Bali's province does not include Bali's most visited area, and it is enough to describe that tourist visit in Bali does not to be spread evenly. Even though Denpasar itself has many attractions and is the closest city to Ngurah Rai International Airport, but in reality, Denpasar has low tourist visits according to the other areas. Denpasar's tourism department stated that the tourists who visit Denpasar are not really doing the travel in Denpasar. Yet, they are only transit to travel to other places in Bali. The growth of the tourism industry will bring market competition, especially in each of the cities and regencies that exist to increase tourist visits. Of course, the low level of Denpasar tourist arrivals is a threat to Denpasar's tourism department.

Some factors influence tourists to come to tourist sites; they are determinants and motivational factors. The determinant factor itself is divided into two categories based on internal support (such as income, tourist health, knowledge of attractions, attitudes, and perceptions). External support includes opinions and perceptions of others about attractions, tourism marketing, media, and political-economic factors related to tourists' origin and destination. As for the motivational factors include physical, cultural, interpersonal, and status/prestige factors. But in some cases, tourists do not always have a motivating factor for travel, but sometimes tourists tend to buy trips impulsively [4]. Denpasar's tourism department itself has made several efforts to increase tourist visits by influencing existing factors, including tourism marketing development, tourism destination development programs, and partnership development programs [5]. But in reality, it is still considered ineffective when viewed in 2019 Denpasar city tourism visits are even far from other districts. 
The development of existing technology has changed the business model of hospitality and tourism, especially in tourism marketing. It follows advancing technology, including information and communications technology (ICT) that has helped community activities, especially in accessing information. The use of information technology used by tourists in accessing tourist information is essential for researchers and business owners for developing the tourism sector. The role of information technology can support tourists through various activities, such as giving inspiration for traveling, providing information, making comparisons, making decisions, planning the tour, communicating, and sharing information after going on a trip [4]. Neuhofer and Buhalis also stated that technology integration could improve tourism experience [6] where the experience itself is one of the products of service management which is considered to create added value in service [8].

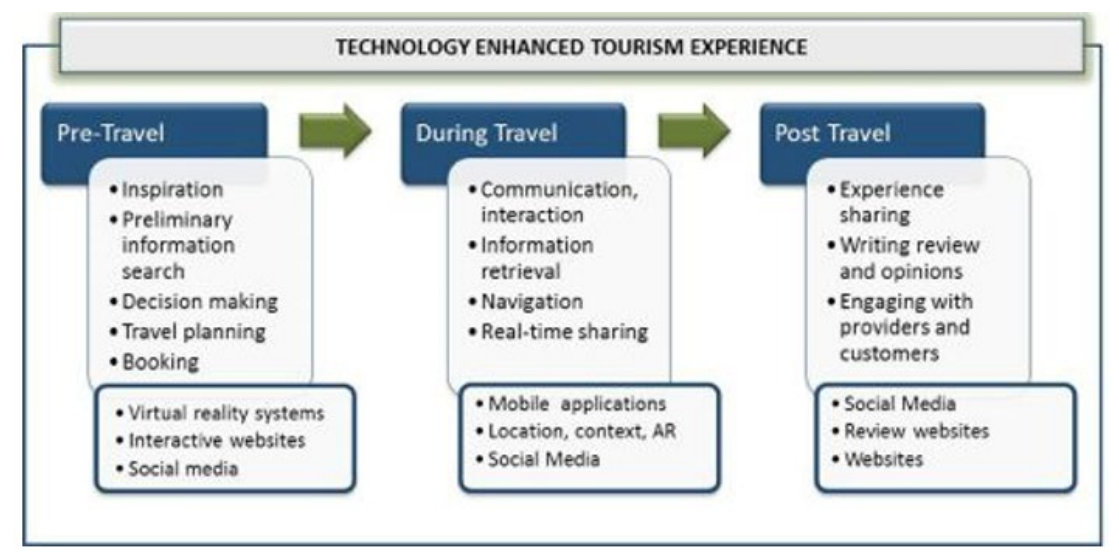

Fig. 1. Technology Enchanced Tourism Experience.

It can be seen in Fig. 1 there are three types of technology that can be used to enhance the tourism experience according to the stages; before traveling, when traveling, and after traveling. In the case of low tourist arrivals in Denpasar, this study intends to utilize information technology according to the research conducted by Ray et al. [9], which states that information is one of the factors that influence tourists' motivation in tourism travel. The development of information technology can also be marked by the growth of internet users globally, and it's increasing from year to year. For example, from 2018 to 2019, internet users worldwide increased by 9.1 percent [10]. It proves that internet penetration can be developed in various aspects, one of which is by maximizing the use of information technology. The development of internet users makes people start switching from conventional activities to become more digitalized. 
People began to switch to using mobile phones to support their daily activities. Of the world's total population, 52 percent access the internet using a mobile phone [10]. Mobile phones also offer good prospects in expanding social approaches, such as obtaining information [11].

In the mobile phone, some applications can be used as the supporting functions in the mobile phone itself or what is referred to as mobile apps. In mobile apps, games are the most category with the highest number of downloads and consumer spending. Games are also the most downloaded mobile apps category in several application markets; Google Play and iOS [10]. Playing games is an aspect of modern culture and a major of entertainment activity for gamers worldwide. Mobile game apps have created a new ecosystem by providing a platform for the gaming landscape, and the growing popularity of eSports, virtual reality (VR) and augmented reality (AR) games in this category makes gamers and non-gamers more interested and considered more attractive to attract gamers and non-gamers into using it [12]. Based on the above phenomenon, researchers decided to use mobile apps based on games to increase tourists' desire to visit a tourist attraction.

Virtual Reality (VR), Augmented Reality (AR), and Mixed Reality (MR) have great potential in promoting tourism and will expand the tourism industry [13]. The design of Augmented Reality as a promotional media has also been carried out by the Japanese government to attract foreign tourists to travel in Sekigahara, Gifu Prefecture, Japan. The Japanese government made an application called "Sekigahara Sightseeing Navi" to attract tourists to visit the city of Sekigahara [13]. Whereas in its relation to enhancing the tourism experience, the tourism industry has taken steps to use Augmented Reality technology in developing tourism experiences that have never been felt before [14]. Some application developers have also taken the opportunity to use AR in creating applications that can enhance the tourist experience, for the example is Enuke Software, where the application can describe the situation directly at a tourism location with various information features such as transportation, weather, tourism destinations, and other information [15]. Some tourism applications based on Augmented Reality also provide features that can describe information on tourist sites. However, existing features are less attractive to attract the tourists to visit a tourist location, and do not offer value-added more than just providing the information.

From these problems or an opportunity, the ineffectiveness of the existing Mobile Augmented Reality (MAR) tourism apps attracts tourists to visit a 
tourist location. This research propose the development of the concept of the MAR apps by adopting the Pokemon-GO game application reference by providing one of the features that are not only informative but can be fun (games). Tourism MAR is designed to offer multiplier effects to the economic sector for tourism stakeholders through the functions in them. The use of Pokemon-GO references in the development of this concept itself is based on the success of Pokemon-GO as the largest Mobile Augmented Reality (MAR) game in the world and became the best-selling game in the USA with just a few hours after its release. And based on some previous research on the important role of Augmented Reality technology in the tourism sector, it can be concluded that Augmented Reality can be one solution that can increase tourists' motivation in visiting a tourist attraction.

\section{Literature Review}

This chapter explains theories related to Service Management as a core theory, Design Thinking as a problem-solving theory, Tourism, and Augmented Reality.

\subsection{Service Management}

The service sector dominates economic developments in modern industries. The service itself is a part of economic activities whose output is not a physical product, but the product is consumed when it is produced and provides valueadded in the form of comfort, entertainment, punctuality, and others [8]. Service is part of serving consumers or users, where consumers or users are involved during its process [16]. The service economy's characteristic has moved from the origin of a transactional service to an experience-based relationship. Experience can create value-added by involving customers through the creation of memorable personal experiences [8]. Experience-based services themselves can be distinguished based on the level of customer participation and the level of interaction with the environmental relationship. For instance, in the entertainment aspect, for example in watching movies, customers in that aspect have the lowest level of participation and interaction with the environment, while the escapism aspect has a high level of participation and interaction, for example in scuba diving, because gaining experience requires a lot of customer involvement. 


\subsection{Design Thinking}

Design thinking is a tool for solving human-centered problems that emphasize empathy, collaboration, co-creation, and stakeholders to unlock creativity and innovation, where design thinking includes designing great or feasible ideas or solutions. The key to this process is to empathize with the endusers of the product to uncover unmet needs by understanding their beliefs, values, motivation, behavior, pain, advantages, and challenges, and to provide innovative solution concepts [17]. The design thinking process generally consists of the stages of understanding the problem, observe, point-of-view in defining the problem, ideate to finding and selecting ideas, develop the prototype, and testing.

\subsection{Tourism}

Tourism is clearly defined as a set of relationships, services, and facilities resulting from inter-community movements [4]. In the concept of tourism itself, there is a Tourism Multiplier Effect, which means that tourism has other impacts in terms of the economy involved in it. There are two main types of effects that can be identified; there are indirect effects and induction effects. The indirect effect comes from consumption between suppliers of tourism goods and services. And conversely, the income of workers and tourism business owners is spent on obtaining various goods and services, which leads to the induction effect [4].

\subsection{Augmented Reality}

When Augmented Reality technology is applied in tourism, real images, and virtual images will be combined; information such as location, road map, density, average price, and comments related to tourism objects will be displayed on the camera. Users will have more consistent information about the target location [18]. AR is a technology that shows the real environment in realtime, either directly or indirectly, coupled with the presentation of information generated by virtual computers. [19] Augmented Reality aims to simplify the lives of users by bringing virtual information not only to their immediate environment but also to indirect display of real-world environments, such as live streaming video. 


\section{Research Design and Methodology}

This research was conducted using the design thinking approach through text mining techniques and descriptive qualitative method to carry out the observation stage in design thinking. The results obtained can be able to explain how a problem can occur and how solutions can be provided through the ideate stage in design thinking.

\subsection{Research Question}

The purpose of this study is to discover how the concept of Mobile Augmented Reality (MAR) tourism can be developed based on tourists' needs and desires for increasing tourism experiences based on Denpasar tourism case. The research questions are as follows:

1. What is tourists' perception of the attractions in Denpasar Bali?

2. Is the concept Mobile Augmented Reality (MAR) Tourism makes tourists interested in using it as an effort to enhance the tourism experience?

3. How the Tourism MAR feature should be developed based on tourists' needs and desires for increasing tourism experiences based on the Denpasar tourism case?

\subsection{Research Method}

This study focuses on four from six steps in design thinking: understanding, observing, point-of-view, and ideate stage as the research output. As shown in Fig. 2. For the first stage in design thinking, researchers identify problems through literature from several studies, previous research, and field studies to strengthen the research phenomenon by conducting interviews with the Denpasar Tourism Office. After identifying the problem, the researcher sets the research objectives and problem boundaries so that the research is more focused and directed. After finding the problem, researchers began to make observations by identifying potential consumers through secondary data quoted from a study conducted by the Pew Research Center on smartphone ownership in the World to determine who consumers would be targeted in developing this application. The selection of secondary data is based on the characteristics of the target market that would be developed; the mobile phone market.

At the point-of-view stage, the researchers identified consumer problems through text mining techniques, identifies apps features requirement based on questionnaire distribution techniques to identify consumer needs and desires. 
To identify the tourists' problems, researchers took data from the reviews of tourists who have visited attractions in Denpasar through TripAdvisor as an online travel agent platform, which provides a huge amount of user review data of several tourism objects. We use user-reviewed data as user-generated content (UGC), in this case, because the UGC has high credibility, and it was written directly by consumers who have experienced it so proven to be trustworthy [20]. So that the reviews given by customers can identify the problem that happened in reality.

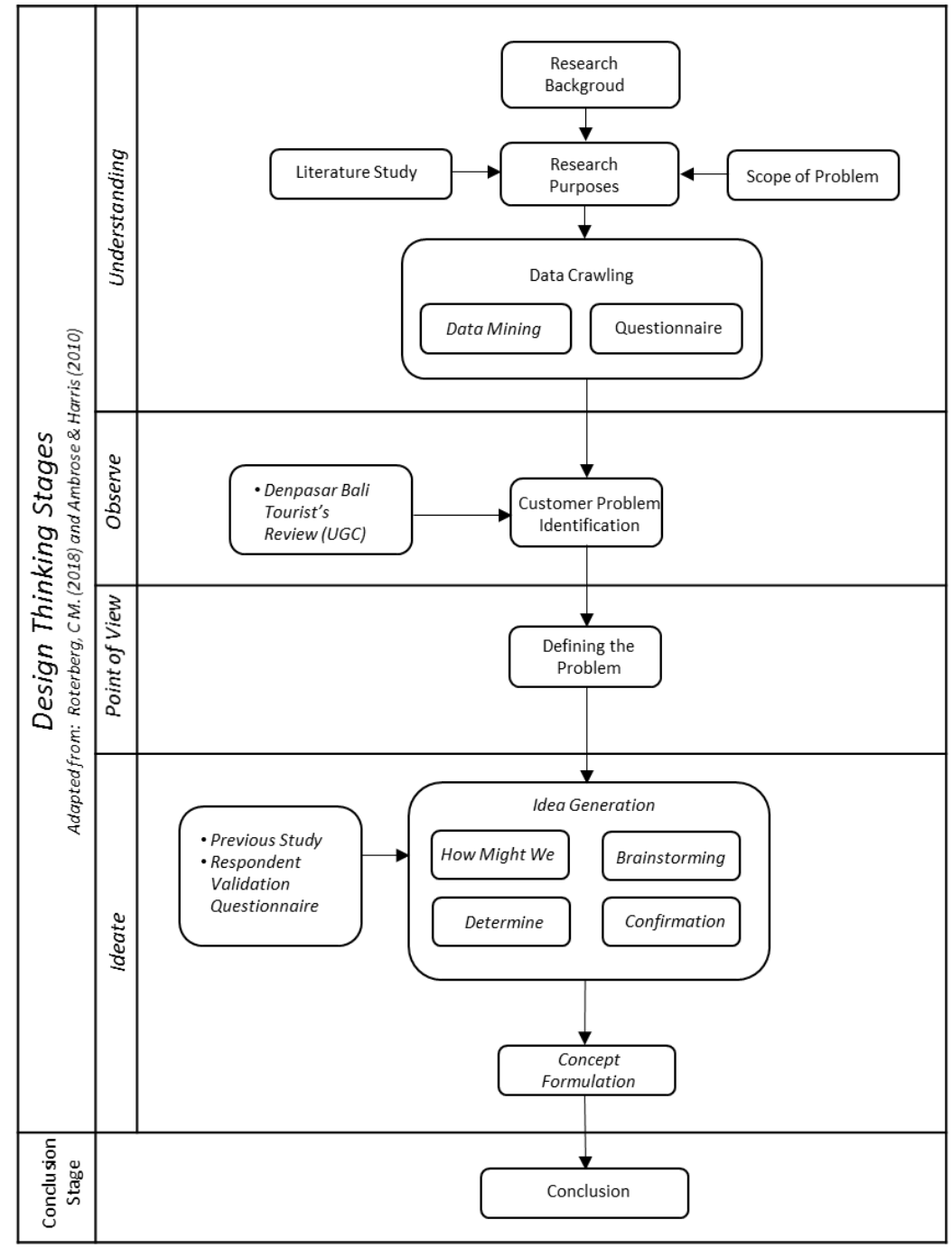

Fig. 2. The Research Flow 
UGC data will be processed through machine learning to get valuable information that can be used as an insight in the research. The processed data in the pre-processing stage, where the data be prepared and cleaned so that unnecessary data does not include in the analysis stage and did not cause bias, as can be seen in Fig. 3

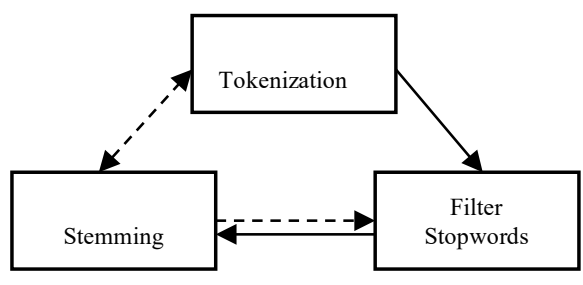

Fig. 3. Preprocessing Flow

After knowing the driving factors of existing problems, researchers collect the ideas in the concept of Tourism MAR based on tourists' needs and desires who have visited Denpasar through three stages. The first stage is conducting a study based on previous research references as a basic concept for developing mobile apps, so the ideas given by consumers remain within the scope of the study. Furthermore, after establishing the basic concept through reference to previous research, the researcher defines the primary design direction to determine how we can conduct the design compares with competitors' products, brands, and organizations. In this case, researchers can think in directions certain to generate new ideas from pre-existing designs [21]. Several concepts are informing basic design directions, one of which is the point of difference. It is a combination of values and attributes that can distinguish a product or company from all products or other similar companies [20]. Because this research is developing several existing products, the researcher makes a point of difference to show the position of difference that distinguishes this study from other similar studies. Thus, this is included in the form of divergence. It involves the development of designs used by companies or similar brands. It shows the renewal of the development position among the previous designs [21]. All the main AR topics that we proposed on this research is based on the comparison between previous studies with similar topics that have been researched about augmented reality applications in tourism fields, and we conclude that in the previous studies bellow, nine topics that appear on the future AR or VR technology as can be seen in Table I bellow, they are; Virtual Tour (1) or Real Tour (2), Marker (3), Provide Information (4), Location-Based Service (5), Social Media Integrated (6), Physical and Sensory Stimulation (7), Well-Being Development (8) dan Artificial Intelligence (9). 
Table 1. Tourism MAR Main Topics Mapping Based on Previous Studies.

\begin{tabular}{|c|c|c|c|c|c|c|c|c|c|c|c|}
\hline No. & Pengarang & Technology & 1 & 2 & 3 & 4 & 5 & 6 & 7 & 8 & 9 \\
\hline 1 & Koikawa, K. (2016). & $\mathrm{AR}$ & $\mathrm{v}$ & $\mathrm{V}$ & $\mathrm{V}$ & $\mathrm{v}$ & & $\mathrm{v}$ & $\mathrm{v}$ & $\mathrm{v}$ & \\
\hline 2 & Paavilainen, J., et al. (2017). & $\mathrm{AR}$ & $\mathrm{v}$ & $\mathrm{v}$ & $\mathrm{v}$ & $\mathrm{v}$ & & $\mathrm{v}$ & $\mathrm{v}$ & $\mathrm{v}$ & \\
\hline 3 & He, Z., et al. (2018). & AR & $\mathrm{v}$ & & & $\mathrm{v}$ & & & & $\mathrm{v}$ & \\
\hline 4 & $\begin{array}{l}\text { Loureiro, S. M. C., et al. } \\
(2020) .\end{array}$ & VR \& AR & $\mathrm{v}$ & $\mathrm{v}$ & & & & & & & \\
\hline 5 & Neuburger, L., et al. (2018). & VR \& AR & $\mathrm{v}$ & $\mathrm{v}$ & $\mathrm{v}$ & $\mathrm{v}$ & $\mathrm{v}$ & & & $\mathrm{v}$ & \\
\hline 6 & Aluri, A. (2017). & $\mathrm{AR}$ & & $\mathrm{v}$ & $\mathrm{v}$ & $\mathrm{v}$ & $\mathrm{v}$ & & $\mathrm{v}$ & & \\
\hline 7 & $\begin{array}{l}\text { Demir, Ö. F., \& Karaarslan, } \\
\text { E. (2018). }\end{array}$ & $\mathrm{AR}$ & $\mathrm{v}$ & & & $\mathrm{v}$ & & & & $\mathrm{v}$ & \\
\hline 8 & Katkuri, P. K., et al. (2019). & VR \& AR & $\mathrm{v}$ & & & $\mathrm{v}$ & & & & $\mathrm{v}$ & \\
\hline 9 & $\begin{array}{l}\text { Kadi, D., \& Santoso, A. J. } \\
\text { (2017). }\end{array}$ & $\mathrm{AR}$ & $\mathrm{v}$ & & & $\mathrm{v}$ & & & & $\mathrm{v}$ & \\
\hline 10 & Nóbrega, Ret., al. (2017). & $\mathrm{AR}$ & $\mathrm{v}$ & & & $\mathrm{v}$ & & & & $\mathrm{v}$ & \\
\hline 11 & Brito, C. D. L. N. A. (2015). & $\mathrm{AR}$ & $\mathrm{v}$ & & & $\mathrm{v}$ & & & & $\mathrm{v}$ & \\
\hline 12 & Llerena, J., et al. (2018). & $\mathrm{AR}$ & $\mathrm{v}$ & & & $\mathrm{v}$ & & & & $\mathrm{v}$ & \\
\hline 13 & $\begin{array}{l}\text { Safitri, R., Yusra, D. S., et al. } \\
(2017) \text {. }\end{array}$ & $\mathrm{AR}$ & $\mathrm{v}$ & & & $\mathrm{v}$ & & & & $\mathrm{v}$ & \\
\hline 14 & Chang, Y. S., et al. (2018). & $\mathrm{AR}$ & $\mathrm{v}$ & & & $\mathrm{v}$ & & & & $\mathrm{v}$ & \\
\hline 15 & Sulaiman, S., et al. (2019 & $\mathrm{AR}$ & $\mathrm{v}$ & & & $\mathrm{v}$ & & & & $\mathrm{v}$ & \\
\hline 16 & Fannisa. (2020). & $\mathrm{AR}$ & & $\mathrm{v}$ & $\mathrm{v}$ & $\mathrm{v}$ & $\mathrm{v}$ & $\mathrm{v}$ & & $\mathrm{v}$ & $\mathrm{v}$ \\
\hline
\end{tabular}

To determine the feature that appear in the apps, this research uses the four realms of experience theory as the basic concept to shape the features. Because tourism is an industry that provides a service experience, so we use three of four realms of experience in these studies, they are; esthetics, entertainment, and escapism. Furthermore, in the idea generation stage, researchers use the theme of thinking; User-Centered Design (UCD) because UCD focuses on the design of a service based on the needs, desires, and limitations of the user [21]. The questionnaire was distributed to confirm whether the features to be designed in the application would meet the user's needs, or not, and then the respondents were given the freedom to provide their ideas in the development of Tourism MAR concept. 


\section{Result and Analysis}

This chapter discusses the results of observe, point-of-view, and ideate stage in design thinking. This includes an outline of the proposed development of the Tourism MAR concept.

\subsection{Observe}

\section{a. Emphaty Map}

Before entering traveler reviews into the empathy map, we conducted topic modeling using the $\mathrm{R}$ programming language and processed them using the LDA-Based topic modeling algorithm. The data modeled is tourist review data taken through the TripAdvisor site, and preprocessing was previously carried out so that the processed data does not show biased results. Fig. 4 is the result of data processing collected from the reviews of tourists who have visited tourist sites in the city of Denpasar, Bali.

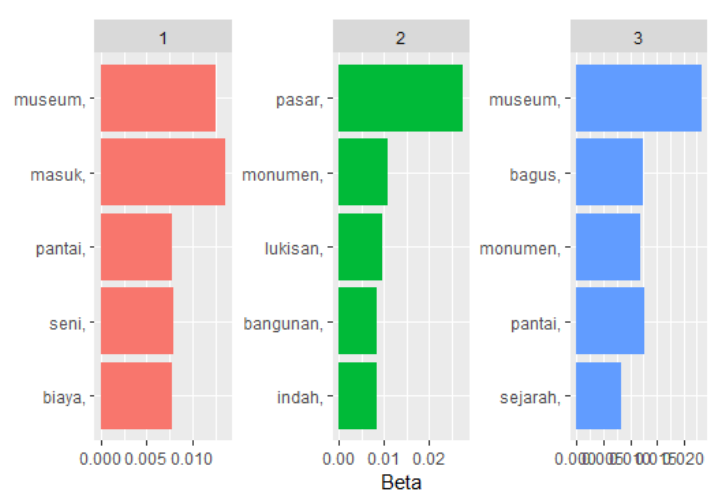

Fig. 4. Topic Modeling based on the Tourist' Perception

Fig. 4 shows the general topic of modeling results from the overall review of tourists who have visited Denpasar. The number on the x-axis is called beta, which shows how often the word appears on a topic. The higher the beta, the more often a word appears on the topic. It can be seen on the topic that shows several words; "museum", "masuk", "pantai", "seni", and "biaya". Based on the words that appear on the first topic, it discusses the entry fee information of the tourist destination. If explored further, most of the online travel agent website does not provide information about prices, nor how to reach a tourist location. On the second topic, there are the words "pasar", "monument", "lukisan", "bangunan", and "indah". The words discuss the tourism infrastructure, especially regarding the existing buildings. The "indah" word represents that so far, when tourists visit tourist destinations in Denpasar, tourists feel quite 
satisfied with the buildings being maintained. Next is the third topic with the words "musium", "bagus", "monument", "pantai", and "sejarah". These words tell about the iconic tourist destinations in Denpasar, such as museums, monuments, and beaches. Subsequently, there are adjectives such as "bagus", which represent that of the destinations in Denpasar, tourists already feel quite satisfied with the existing tourist infrastructure.

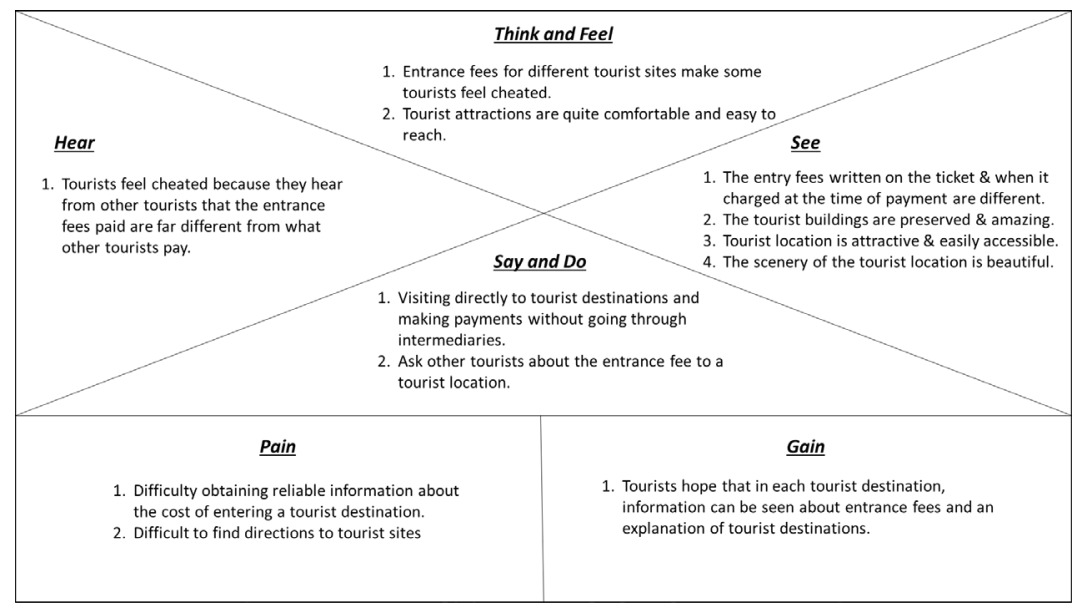

Fig. 5. Tourist' Emphaty Map Summary

Based on the results of the modeling topics above, it can be concluded that there is one topic that is a factor driving the low visit in tourist sites in Denpasar. In comparison, the other two topics discuss tourist satisfaction related to existing tourist sites. Of the three topics, there is one topic that discusses the problems faced by tourists, namely the first topic that discusses the problem of lack of information about the entrance fees imposed on particular destinations, causing disinformation for some tourists. Based on what has been examined from the representation of the word, that conclusions can be drawn based on the problem of the non-maximum tourist visits in the city of Denpasar, Bali is not caused by inadequate services or destinations. Because the results of the research stated that in terms of service and the tourism destination infrastructure itself, it is quite good when viewed from the representation of tourists who have visited Denpasar Bali. Furthermore, the results of tourist perception mapping can be summarized into an empathy map, as can be seen in figure 5 . 


\subsection{Point of View}

Based on what has been researched from the representation of the word, it can be concluded that inadequate services or destinations do not cause the problem of not maximizing tourist visits in Denpasar Bali. Because the results of this research state that in terms of service and the infrastructure of the tourist destination itself, it is quite good when viewed from the representation of reviews of tourists who have visited Denpasar Bali. So, the lack of information, especially regarding the entrance fee, is a problem felt by tourists when visiting tourist destinations in Denpasar, Bali.

\subsection{Ideation}

\section{a. How Might We}

Based on the results of the problems that have been identified through the inspiration phase, "How Might We" is used to finding opportunities in designing a solution, and the knowledge gained from the inspiration phase can be used to suggest questions to be mapped in "How Might We" as follows.

Table 2. How Might We Question.

\begin{tabular}{|l|r|}
\hline Insight & \multicolumn{2}{|c|}{ How Might We } \\
\hline $\begin{array}{l}\text { 1. Many tourists do not know } \\
\text { information about tourist } \\
\text { destinations, such as the entry }\end{array}$ & $\begin{array}{l}\text { 1. How can we provide } \\
\text { information about tourist } \\
\text { destinations easily accessible } \\
\text { to both domestic tourists and }\end{array}$ \\
$\begin{array}{l}\text { 2. Foreign tourists who do not } \\
\text { foreign tourists? }\end{array}$ \\
$\begin{array}{l}\text { know the entry fee information } \\
\text { tend to be fraudulent by some } \\
\text { ticket sellers. }\end{array}$ \\
$\begin{array}{l}\text { 2. How can tourists find out } \\
\text { information about a } \\
\text { destination, especially } \\
\text { be lied to after learning that the } \\
\text { entrance fee they pay is different } \\
\text { from what other tourists pay. }\end{array}$ & $\begin{array}{l}\text { regarding the real-time entry } \\
\text { fee for tourist sites and } \\
\text { according to the tour } \\
\text { manager's price? }\end{array}$ \\
\hline
\end{tabular}

\section{b. Brainstorming}

Brainstorming in this study was carried out by reviewing previous research and consumers who were at the center of designing the solutions 
presented, namely tourists. Furthermore, the basic ideas for answering the "How Might We" question are obtained through previous research.

Table 3. Article Selection.

\begin{tabular}{|c|c|c|c|}
\hline KEYWORDS & $\begin{array}{c}\text { TOTAL } \\
\text { SEARCH } \\
\text { (Article) }\end{array}$ & $\begin{array}{c}\text { SELECTION- } \\
\text { I } \\
\text { (By Title) }\end{array}$ & $\begin{array}{c}\text { SELECTION-II } \\
\text { (By Abstract) }\end{array}$ \\
\hline $\begin{array}{c}\text { "Tourism } \\
\text { Information" }\end{array}$ & 1350 & 32 & 10 \\
\hline \multicolumn{2}{r|}{ Total $=$} & 32 & 10 \\
\hline
\end{tabular}

Based on the ten previous studies, it can be concluded that there are six studies that state that the mobile application can be one of the ideas in answering the How Might We question, while there are other ideas in the form of using Augmented Reality. So it can be concluded that mobile application is considered quite effective in presenting tourist destinations information because several studies have stated that the mobile application itself is felt to be more personal in conveying information. Considered more useful, easy to use, and compatible, it can save time, is more efficient and effective, and can provide reliable and unreliable access to information.

Furthermore, based on the phase 1 brainstorm results, it is necessary to reconfirm to the end consumer whether the solution can answer the existing problems. Moreover, questionnaires were distributed to respondents regarding whether they were interested in using the Mobile Application to view tourist objects.

Fig. 6. Brainstorming Phase II

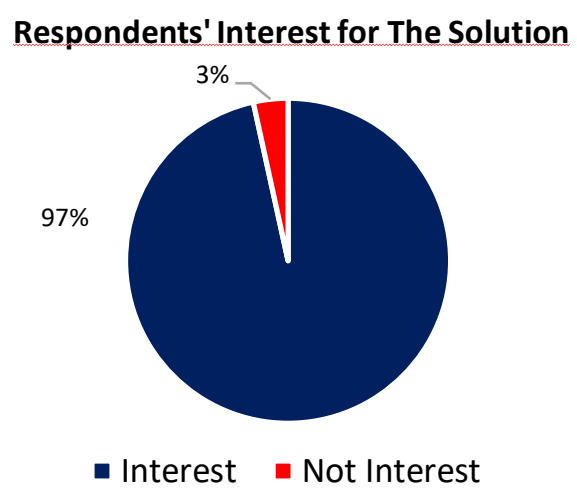


As can be seen in Fig. 6, rom the existing questionnaire results, the majority of $97 \%$ of the 494 respondents collected agree that they are interested in holding a tourism application to underlying the development of the concept of mobile tourism apps.

\section{c. Determine}

Based on the brainstorming stages, it was found that the majority of respondents were interested in using tourism applications in accessing tourist information. Because the tourism application scope is quite broad, this application will be straitened in its features and uses based on the scope of tourist information presentation. The dimension of experience will be revalidated to tourists to choose whether the application's features can be a solution and solve existing problems.

\section{d. Confirmation}

In this confirmation stage, the ideas that have been collected and developed from various sources are validated by the end consumers who use the solutions in the future by using the theme of User-Centered Design (UCD) thinking, as can be seen in Table. 4 regarding the characteristics of research respondents.

It can be seen in Table. 3 that there are respondents from seven continents who can be assumed as foreign tourists and respondents from Indonesia themselves who are considered to be domestic tourists. Respondents were dominated by domestic tourists, with 433 respondents from Indonesia, and subsequently by foreign tourists with 61 respondents from Asia. The gender who dominated is $71 \%$ of women, while male respondents are $29 \%$ with the most-aged by $21-31$ years. Out of the total 494 respondents who visited Bali, $91 \%$ of the total respondents had visited Denpasar so that it could be said that the respondent had visited one of the places of interest in Denpasar. 
Table 3. Respondent Characteristic Data.

\begin{tabular}{|c|c|c|}
\hline Category & $\begin{array}{l}\text { Frequency } \\
\text { (n) }\end{array}$ & $(\%)$ \\
\hline \multicolumn{3}{|l|}{ Gender } \\
\hline Man & 144 & 29 \\
\hline Woman & 350 & 71 \\
\hline \multicolumn{3}{|l|}{ Ages } \\
\hline$<20$ years old & 56 & 11 \\
\hline $21-30$ years old & 383 & 78 \\
\hline $31-40$ years old & 49 & 10 \\
\hline $40-50$ years old & 6 & 1 \\
\hline$>50$ years old & 0 & 0 \\
\hline \multicolumn{3}{|l|}{ Origin } \\
\hline Indonesia & 433 & 88 \\
\hline Asia & 47 & 10 \\
\hline Europe & 6 & 1 \\
\hline Australia & 3 & 1 \\
\hline America & 2 & 0 \\
\hline Middle East & 2 & 0 \\
\hline Antarctica & 1 & 0 \\
\hline \multicolumn{3}{|c|}{ Purpose in Visited Bali } \\
\hline Vacation & 430 & 72 \\
\hline Business & 19 & 3 \\
\hline Work & 66 & 11 \\
\hline Educational Reason & 47 & 8 \\
\hline Others & 35 & 6 \\
\hline \multicolumn{3}{|c|}{ Interest of Respondents towards MAR Tourism } \\
\hline Yes & 477 & 91 \\
\hline No & 17 & 9 \\
\hline
\end{tabular}

We proposed four aspects that can be used to develop the feature and appear in Tourism MAR apps. We designed the feature based on the previous study and from four realms of experience theory. For each aspect, we designed at least several features that appear in it as shown below:

a. Visual Information Aspects

1. Operational information on tourism object (i.e. price of admission, operation hours, etc.)

2. Real-time information about how many people stay at the location of the tourism object 
3. Information how to reach a tourism location, vehicles that can be used to reach it, and tourism facilities

4. Vehicles can be used to reach out the tourism object. (i.e city bus, online transportations, and other public vehicles).

5. Near place of the tourism object like restaurants / hotels / mini markets / souvenir shops.

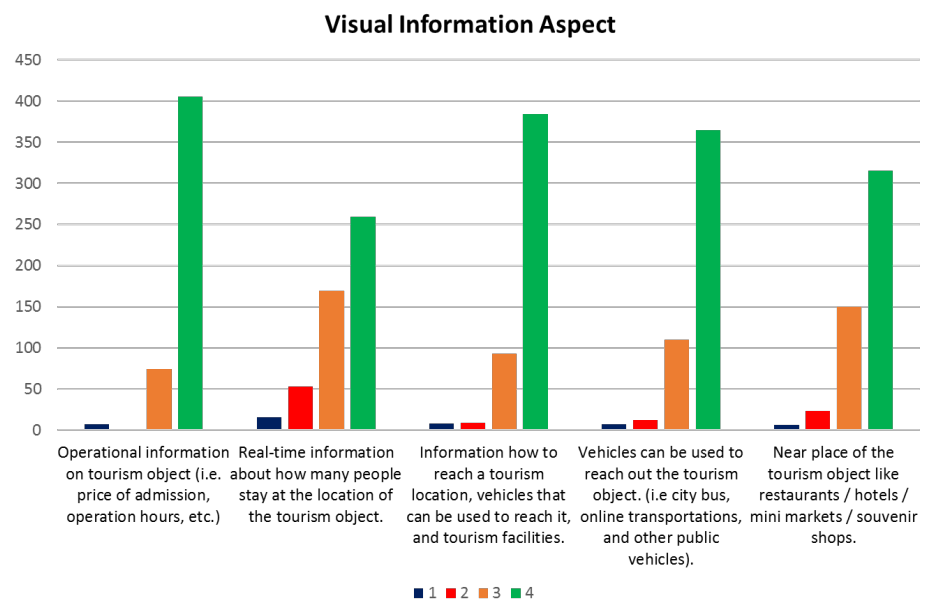

Fig. 7. Idea Generation: Visual Information Aspects

Based on the design features that could appear in the apps, all respondents stated that all the features above are important to provide in the application.

b. Entertaiment Aspects

1. Game feature when the user plays it and completes all the mission given, the user can get some points that can be exchanged into travel package discounts and vouchers

2. Application features that can be used to share information through existing social media like Twitter, Facebook, and Instagram. 


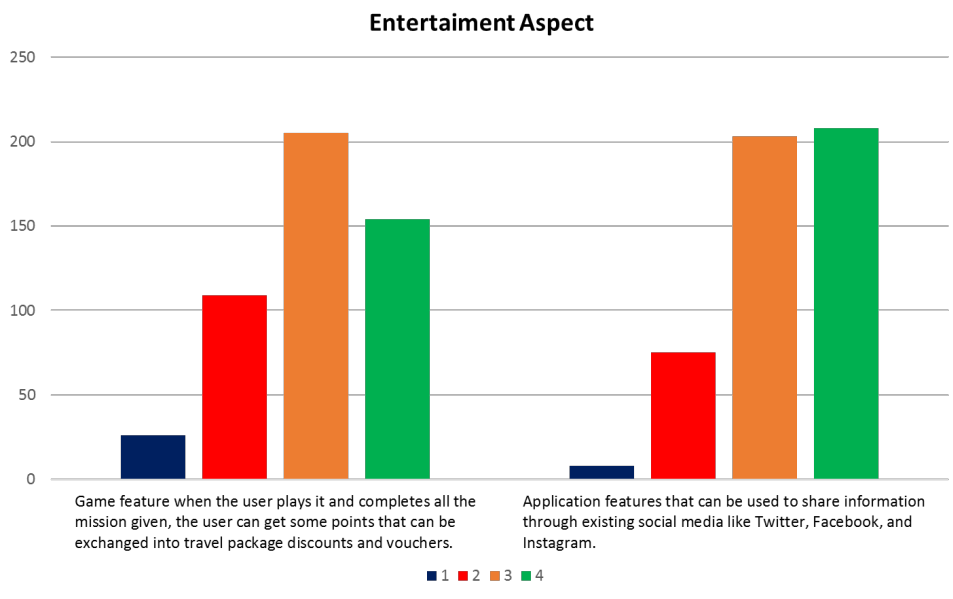

Fig. 8. Idea Generation: Entertainment Aspects

For the first feature, respondents consider that the feature is important, and on the second feature, the respondents assess if the feature is very important.

\section{c. Escapism Aspects}

1. Apps can be a tour guide for the user to explore a tourist location.

2. Apps can allow fellow users to meet in a virtual world through Augmented Reality technology.

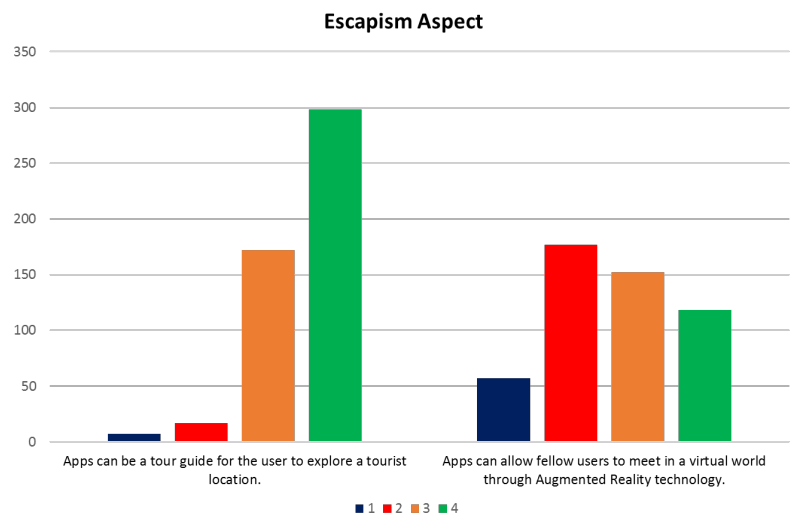

Fig. 9. Idea Generation: Escapism Aspect 
For the first feature, respondents consider it is very important. And for the second function, the respondent considers that the feature is not important in the application.

d. Aesthetics Aspects

1. Attractive application design.

2. The use of pleasant colors.

3. User friendly application display.

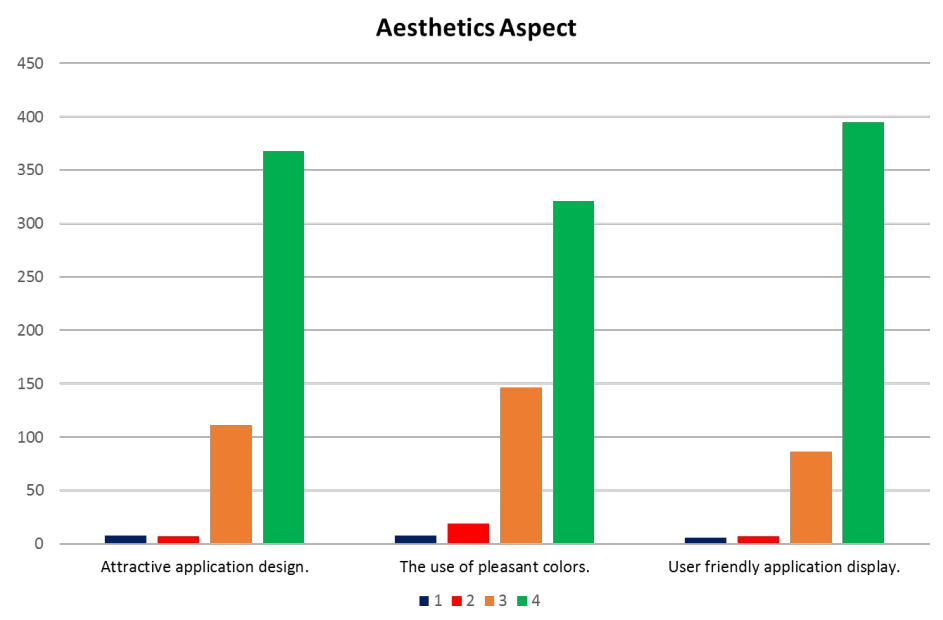

Fig. 10. Idea Generation: Aesthetics Aspects

Of the three functions, respondents considered it very important if the three functions were applied in the application.

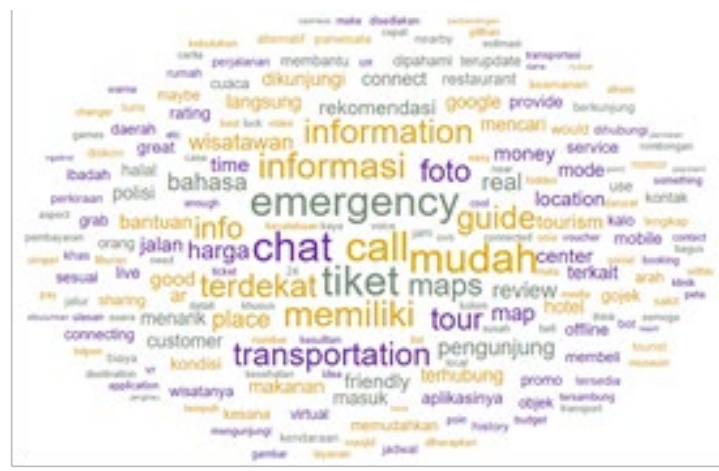

Fig. 9. Idea Generation: Word Cloud Application Feature Suggestions 
In taking the questionnaire data, the researcher included open-ended questions about what other essential features respondents wanted to appear in the application. Researchers have at least 495 ideas and we decide to take the top five ideas most frequently given by respondents to be provided in the application design. To discover the top five ideas, researchers used Word Cloud to see the most appeared words by the respondents' ideas.

The font size of words that appear shows the relevance or frequency of a word in a text document, while other visuals such as color, position, and orientation do not affect the meaning of a word that appears (Lohmann et al., 2015: 114). The bigger the word that appears, the more often the word appears in the respondent's advice. Based on the results of the existing Word Cloud visualization, obtained five words that appear in many suggestions given by respondents, the word is "call" with a weight of 138, "emergency" with a weight of 134 , "tiket" with a weight of 20 , "chat" with a weight of 19 , and "mudah" words with the same weight is 19. The words "emergency" and "call" have a single meaning, which is "emergency call", if seen from the suggestions given, respondents want the emergency call feature to anticipate if things happen, user can easily contact related parties. The third word is "tiket", respondents want a feature that can provide information about the price of a tourist attraction ticket. The fourth-biggest word is "chat", respondents wish for a chatbot feature that can automatically answer questions about tourist sites. The last word is "mudah", from the advice given, respondents expect this application can simplify the user with the features created. Based on the results of consumer validation regarding the features that will be the solution to the existing problems, it can be concluded in Table. 4 as follows.

Table 4. Problem Solution Validation.

\begin{tabular}{|c|c|c|}
\hline $\begin{array}{c}\text { Variable } \\
\text { (Idea) }\end{array}$ & Proposed Features & Validation \\
\hline \multirow[t]{3}{*}{$\begin{array}{l}\text { Visual } \\
\text { Information } \\
\text { Aspect }\end{array}$} & $\begin{array}{l}\text { 1. Operational information on tourism } \\
\text { object (i.e. price of admission, operation } \\
\text { hours, etc.) }\end{array}$ & $\sqrt{ }$ \\
\hline & $\begin{array}{l}\text { 2. Real-time information about how many } \\
\text { people stay at the location of the tourism } \\
\text { object. }\end{array}$ & $\sqrt{ }$ \\
\hline & $\begin{array}{l}\text { 3. Information how to reach a tourism } \\
\text { location, vehicles that can be used to } \\
\text { reach it, and tourism facilities. }\end{array}$ & $\sqrt{ }$ \\
\hline
\end{tabular}




\begin{tabular}{|c|c|c|}
\hline & $\begin{array}{l}\text { 4. Vehicles can be used to reach out the } \\
\text { tourism object. (i.e city bus, online } \\
\text { transportations, and other public } \\
\text { vehicles). }\end{array}$ & $\sqrt{ }$ \\
\hline & $\begin{array}{l}\text { 5. Near place of the tourism object like } \\
\text { restaurants / hotels / mini markets / } \\
\text { souvenir shops. }\end{array}$ & $\sqrt{ }$ \\
\hline $\begin{array}{l}\text { Entertainme } \\
\text { nt Aspect }\end{array}$ & $\begin{array}{l}\text { 1. Game feature when the user plays it and } \\
\text { completes all the mission given, the user } \\
\text { can get some points that can be } \\
\text { exchanged into travel package discounts } \\
\text { and vouchers. }\end{array}$ & $\sqrt{ }$ \\
\hline & $\begin{array}{l}\text { 2. Application features that can be used to } \\
\text { share information through existing social } \\
\text { media like Twitter, Facebook, and } \\
\text { Instagram. }\end{array}$ & $\sqrt{ }$ \\
\hline $\begin{array}{l}\text { Escapism } \\
\text { Aspect }\end{array}$ & $\begin{array}{l}\text { 1. Apps can be a tour guide for the user to } \\
\text { explore a tourist location. }\end{array}$ & $\sqrt{ }$ \\
\hline & $\begin{array}{l}\text { 2. Apps can allow fellow users to meet in a } \\
\text { virtual world through Augmented Reality } \\
\text { technology. }\end{array}$ & $\mathrm{X}$ \\
\hline Esthetics & 1. Attractive application design. & $\sqrt{ }$ \\
\hline Aspect & 2. The use of pleasant colors. & $\sqrt{ }$ \\
\hline & 3. User friendly application display. & $\sqrt{ }$ \\
\hline $\begin{array}{l}\text { Open } \\
\text { Question }\end{array}$ & $\begin{array}{l}\text { What feature suggestions can you provide in } \\
\text { designing this application? (For example, } \\
\text { the application must have an emergency call } \\
\text { feature, etc.) }\end{array}$ & $\begin{array}{l}\text { Emergenc } \\
\text { y call, \& } \\
\text { chat bot } \\
\text { feature. }\end{array}$ \\
\hline
\end{tabular}

\section{Conclusion}

1. Based on the tourist perception about attractions in Denpasar Bali, the problem of the non-maximum tourist visits in the city of Denpasar is not caused by poor service or destination. Because the results stated that both the service and infrastructure are quite good. The only problem that appears in tourist perception is the lack of information in every destination that causes disinformation for some tourists. 
2. The majority $(91 \%)$ of respondents stated that they would be interested in using Tourism MAR to enhance their experience in the future, which the features can fulfill one aspect; visual information. And three realms of experiences; entertainment, aesthetic, and escapist.

3. Respondents assume that based on the services and features designed in all four aspects, they are important if they appear in the application. Where the services and features that appear in Tourism MAR consist of; operational information on tourism object, real-time information about tourist' intensity in the destination, information on how to reach a tourism location, vehicles can be used to reach out the tourism object, and near a place of the destination for the visual information aspect; game and social media sharing feature for entertainment aspect; tour guide and virtual meet feature for escapism aspect; and for the design, respondent think that attractive, pleasant color, and user friendly is important for aesthetics aspect. 


\section{References}

[1] Kementerian Pariwisata dan Ekonomi Kreatif RI (2019). Data Kunjungan Wisatawan $\begin{array}{llll}\text { Mancanegara Bulanan } & \text { Tahun } & \end{array}$ https://www.kemenparekraf.go.id/index.php/post/data-kunjungan-wisatawanmancanegara-bulanan-tahun-2019 [3 Februari 2020].

[2] UNWTO, T. O. (2014). Tourism Highlights, 2014 edition. World.

[3] Kementerian Pariwisata Republik Indonesia. (2018). Rencana Strategis Pengembangan Destinasi dan Industri Pariwisata 2018-2019. [online]. http://www.kemenparekraf.go.id/index.php/categories/rencana-strategis [5 Februari 2020].

[4] Lohmann, S., Heimerl, F., Bopp, F., Burch, M., \& Ertl, T. (2015). Concentri cloud: Word Cloud visualization for multiple text documents. In 2015 19th International Conference on Information Visualisation (pp. 114-120). IEEE.

[5] Dinas Pariwisata Kota Denpasar. (2018). Profil Pariwisata Kota Denpasar. [online]. https://pariwisata.denpasarkota.go.id/ [6 Februari 2020].

[6] Neuhofer, B., Buhalis, D., \& Ladkin, A. (2012). Conceptualising technology enhanced destination experiences. Journal of Destination Marketing \& Management, 1(1-2), 36-46.

[7] Fitzsimmons, J. A., \& Fitzsimmons, M. J. (2011). Service Management: Operations, Strategy, Information Technology. New York: McGraw-Hill.

[8] Ray, Nilanjan., Dilip, Kumar D., dan Kumar, Raj. (2018). Tourism Marketing A Strategic Approach. USA: Apple Academic Press Inc.

[9] We Are Social, H. (2019). The global digital report 2019. [online]. https://wearesocial.com/global-digital-report-2019 [15 Mei 2020].

[10] Kenning, M M. (2007). ICT and Language Learning From Print to the Mobile Phone. New York: Palgrave MacMillan.

[11] Aluri, A. (2017). Mobile augmented reality (MAR) game as a travel guide: insights from Pokémon GO. Journal of Hospitality and Tourism Technology.

[12] Koikawa, K. (2016). Ideas to boost tourism. Journal of Global Tourism Research, 1(2), $105-109$.

[13] He, Z., Wu, L., \& Li, X. (Robert). (2018). When art meets tech: The role of Augmented Reality in enhancing museum experiences and purchase intentions. Tourism Management, $68,127-139$.

[14] Nadia Kovach. (2014). Augmented Reality in Tourism. [online]. https://thinkmobiles.com/blog/augmented-reality-tourism/ (2014). [5 Februari 2020].

[15] Johnston, R., Clark, G., dan Shulver, M. (2012). Service Operations Management: Improving Service Delivery. Pearson Education.

[16] Hwa, Lee C., Leow, Jason., Lau, Jun., Ho, Angela., dan Yong, Chia H. (2016). Design thinking: The Guidebook. Singapore: Royal Civil Service.

[17]Demir, Ö. F., \& Karaarslan, E. (2018). Augmented reality application for smart tourism: Gökovar. In 2018 6th International Istanbul Smart Grids and Cities Congress and Fair (ICSG) (pp. 164-167). IEEE.

[18] Carmigniani, J., \& Furht, B. (2011). Augmented reality: an overview. In Handbook of augmented reality (pp. 3-46). Springer, New York, NY.

[19]Bahtar, A. Z., \& Muda, M. (2016). The impact of User-Generated Content (UGC) on product reviews towards online purchasing-A conceptual framework. Procedia Economics and Finance, 37(16), 337-342. 
[20] Ambrose, G., \& Harris, P. (2009). Basics design 08: design thinking. Bloomsbury Publishing.

[21] Taylor, K., \& Silver, L. (2019). Smartphone ownership is growing rapidly around the world, but not always equally. Pew Research Center.

[22] Dolnicar, S., Grün, B., \& Leisch, F. (2018). Market Segmentation Analysis (pp. 11-22). Singapore: Springer. 